\title{
THE EFFECT OF MODERATE INTENSITY FUN AEROBIC GYM ON HDL-C AND LDL-C ON OVERWEIGHT WOMEN
}

\author{
Zanuar Bagus Saputro ${ }^{1}$, Tjitra Wardani ${ }^{2}$, Purwo Sri Rejeki ${ }^{1,2}$ \\ ${ }^{1}$ Sports Health Science, ${ }^{2}$ Department of Physiology, Faculty of Medicine, Universitas Airlangga, Surabaya, Indonesia
}

\section{ABSTRACT}

\begin{abstract}
Overweight and obesity is a major health problem in throughout the world. Hyperlipidemia and obesity are risk factor the occurrence of cardiovascular disease. Exercise is recommended as a therapeutic lifestyle changes because it leads to a variety of health benefits. Fun Aerobic gymnastics aerobics one which is quite popular in the community and a gym. Describe the gymnastics fun aerobic workout's effectiveness against related to prevention of cardiovascular disease with seeing the results before and after doing gymnastics with the result of increasing levels of HDL-c and LDLHDL Ratios as well as lowering LDL-c levels. Using design research one group pretest and posttest design with the subject as many as 19 people and given gymnastics moderate fun aerobic intensity for 45 minutes 3 day a week for 6 weeks. Gymnastics moderate fun aerobic intensity can increase HDL-c and LDL/HDL ratio and $L D L-c$. The paired t test results $H D L-c$ pre test and post test $(p=0.000)$, LDL-c pre test and post test $(p=0,015)$, $H D L / L D L$ Ratio $(p=0.000)$. Mean there are meaningful difference between the before and after of gymnastics. The effect of moderate intensity fun aerobic gym on the increase of $H D L-c$ and $L D L / H D L$ Ratio and a decrease in $L D L$-c in overweight women.
\end{abstract}

Keywords: Gymnastics fun aerobic; $H D L ; L D L ; H D L / L D L$ ratio

\section{ABSTRAK}

Kelebihan berat badan dan obesitas adalah masalah kesehatan utama di seluruh dunia. Hiperlipidemia dan obesitas merupakan faktor risiko yang umum terjadinya penyakit kardiovaskular. Latihan dianjurkan sebagai perubahan gaya hidup terapeutik karena mengarah pada berbagai manfaat kesehatan. Fun Aerobic salah satu senam aerobik yang cukup popular di masyarakat dan tempat kebugaran. Menjelaskan senam fun aerobic terkait dengan beberapa latihan terhadap pencegahan penyakit kardiovaskular dengan melihat hasil sebelum dan sesudah melakukan senam dengan hasil meningkatkan kadar HDL-c dan rasio HDLLDL serta menurunkan kadar LDL-c. Menggunakan rancangan penelitian one group pretest and posttest design dengan subjek sebanyak 19 orang dan diberikan senam fun aerobic intensitas sedang selama 45 menit tiga kali seminggu selama 6 minggu. Senam fun aerobic intensitas sedang dapat meningkatkan HDL-c dan rasio HDL/LDL serta menurunkan LDL-c. Hasil Uji t berpasangan pre test dan post test $H D L-c(p=0,000), L D L-c(p=0,015)$, rasio $H D L / L D L(p=0,000)$. Berarti terdapat perbedaan yang bermakna antara sebelum dan sesudah senam. Senam fun aerobic intensitas sedang berpengaruh terhadap peningkatan HDL-c dan Rasio HDL/LDL dan penurunan LDL-c pada perempuan berat badan berlebih.

Kata kunci: Senam fun aerobic; $H D L-c$; $L D L-c$; rasio $H D L / L D L$

Correspondence: Purwo Sri Rejeki Department of Physiology, Sports Health Science, Faculty of Medicine, Universitas Airlangga, Jalan Prof Dr Moestopo No. 47, Surabaya, Indonesia. Email: purwo_faal@yahoo.com, purwo-s-r@fk.unair.ac.id

pISSN:2355-8393 • eISSN: 2599-056x • doi: http://dx.doi.org/10.20473/fmi.v55i2.14331

- Fol Med Indones. 2019;55:89-92 • Received 8 Mar 2018 • Accepted 20 Sep 2018

- Open access under CC-BY-NC-SA license • Available at https://e-journal.unair.ac.id/FMI/

\section{INTRODUCTION}

Overweight and obesity can cause the total of body fat and lipid profile in the blood rise, thus those suffering from overweight or obesity are prone to disease (Hardani \& Lestariana, 2014). Obesity is a condition caused by the disruption of energy regulation and energy homeostasis. Regulation of the energy homeostasis in the human body is achieved through short term and long term mechanism. The short term mechanism includes the increasing amount of glucose, amino acid, fatty acid, and triglyceride level in blood along with the mechanical stretch in gastrointestinal tract (Rejeki, Argarini, \& Subadi, 2016). It is recorded that the population aged beyond 18 years are $12.6 \%$ skinny and $21.7 \%$ are combination of overweight and obesity. The prevalence of overweight is relatively high on teenage girls than teenage boys (1.5\% girls and $1.3 \%$ boys) (Kurdanti et al 2015). The risk factors causing obesity on adult female according to Diana's research in 
2013 are marriage, household income, domicile area, physical activity, and also energy and carbohydrate intake. Furthermore, genetic factor, psychological factor, inappropriate lifestyle, wrong eating habit, stress and other triggers are also the causes (Wegiarti et al 2017). Obesity in women is expected because of the withdrawal of estrogen levels in the blood. Estrogen receptor activation produce a linear result of the obesity (Rejeki \& Wiyasihati, 2017).

The most important factors that should be considered during the exercise sessions are intensity and duration to gain the major health benefit (Kannan, 2014). Prior researches had proven that the level of high density lipoprotein cholesterol (HDL-C) can be increased and the level of total cholesterol (TC) and low density lipoprotein cholesterol (LDL-C) can be decreased by doing physical exercises regularly both for men and women (Mann, Beedie, \& Jimenez, 2013). Coronary heart disease (CHD) is one of the major causes of morbidity and mortality in most countries and strongly correlates with elevated total cholesterol (TC), low density lipoprotein cholesterol (LDL-C), and high density lipoprotein cholesterol (HDL-C) (Kazeminasab et al 2017).

Therefore, a cheap, safe, joyful, and effective alternative physical exercise needs to be developed to improve lipid profile in the blood. Based on the description above, the research design of this research will further investigate about the effect of fun aerobic gym with the combination of low and high impact movements. The created movements give variation to the physical exercise in order to avoid saturation and quick to fatigue because the movements are not continuously driven with strong beats or soft beats with certain duration on the change of HDL-c and LDL-c levels in blood.

\section{MATERIALS AND METHODS}

This is a field experimental research conducted in the Faculty of Sport Science of the State University of Surabaya. It used one pretest group - a post-test research design involving 19 female subjects aged 19 to 25 years with BMI $23-24.9 \mathrm{Kg} / \mathrm{m}^{2}$ all within the treatment group. All of them were physically fit and were not taking any medicine before doing the fun aerobic gym activity. After the sample had met the target, the research was conducted in schedule for test and for the fun aerobic gym themselves.

The data collection of HDL-c and LDL-c pre-test were conducted in the morning after the subjects were asked to fast in the night before. The treatments of moderate intensity fun aerobic gym were conducted for 45 minutes 3 day a week for 6 weeks. And, the data collection for HDL-c and LDL-c post-test was taken the next morning after the treatment of fun aerobic gym had been conducted for 6 weeks and the subjects were asked to fast the night before taking the data.

The statistical analysis was done by using the 20.0 version of SPSS. The descriptive analysis test calculated the average value and also the deviation. After that, normality test was brought by using Shapiro-wilk. If the normality test results to normal data distribution, then parametric test would be done namely the paired t-test.

\section{RESULTS}

The descriptive analysis of subject characteristics described the average (mean) and standard intersection of age variable, weight, and IBM of the research subjects. Data are provided in Table 1. The Table 2 describes the average (mean) and standard intersection of HDL-c, LDL-c variables and the ratio of HDL/LDL during the fun aerobic gym. After descriptive test was conducted, the normality test was also done by using Saphiro-Wilk test that distributed normal data marked by value of $\mathrm{p}>0.05$. The analysis of paired t-test for HDL-c, LDL-c and the ratio of HDL/LDL showed that there are significant correlation of HDL-c variable ( $p>$ 0.05 ) with $\mathrm{p}=0.000$, while the LDL-c variable has significant correlation $(\mathrm{p}<0.05)$ with $\mathrm{p}=0.015$ and the ratio of HDL/LDL has significant correlation $(\mathrm{p}<0.05)$. The data is provided in Table 3 .

Table 1. The mean and standard deviation values intersection of study subjects

\begin{tabular}{lcc}
\hline \multicolumn{1}{c}{ Variable } & $\mathrm{n}$ & Mean \pm SD \\
\hline Age $($ year $)$ & 19 & $22.00 \pm 1.59$ \\
Height $(\mathrm{cm})$ & 19 & $157.47 \pm 5.243$ \\
Weight $(\mathrm{kg})$ & 19 & $59.84 \pm 3.962$ \\
BMI $\left(\mathrm{Kg} / \mathrm{m}^{2}\right)$ & 19 & $24.10 \pm 0.590$ \\
Age $($ year $)$ & 19 & $22.00 \pm 1.59$ \\
Note: SD $=$ Std deviation; BMI= body mass index; \\
\multicolumn{2}{c}{ n= amount research subject }
\end{tabular}

\section{DISCUSSION}

The treatment of fun aerobic gym with moderate intensity is a treatment by combining low and high impact movements in the main movements. The main activity includes the movements that are more active and discipline to train the particular body parts by enough repetition.

Table 2. The mean and standard deviation values of HDL-c, LDL-c, and HDL/LDL Ratio 


\begin{tabular}{|c|c|c|c|c|}
\hline & \multicolumn{3}{|c|}{ Mean \pm SD } & \\
\hline Variable & $\mathrm{n}$ & Pre & Post & $\mathrm{P}$ \\
\hline HDL-c (mg/dl) & 19 & $52.68 \pm 6.421$ & $59.58 \pm 7.631$ & $0.587 *$ \\
\hline LDL-c (mg/dl) & 19 & $103.26 \pm 14.884$ & $95.05 \pm 14.269$ & $0.219^{*}$ \\
\hline Ratio HDL/LDL & 19 & $0.514 \pm 0.057$ & $0.635 \pm 0.089$ & $0.165^{*}$ \\
\hline
\end{tabular}

Table 3. Paired t test Results HDL-c, LDL-c and HDL /LDL Ratio

\begin{tabular}{ccccc}
\hline \multicolumn{5}{c}{ Mean \pm SD } \\
\hline Variable & $\mathrm{n}$ & Pre & Post & $\mathrm{P}$ \\
\hline HDL-c $(\mathrm{mg} / \mathrm{dl})$ & 19 & $52.68 \pm 6.421$ & $59.58 \pm 7.631$ & $0.000^{*}$ \\
LDL-c $(\mathrm{mg} / \mathrm{dl})$ & 19 & $103.26 \pm 14.884$ & $95.05 \pm 14.269$ & $0.015^{*}$ \\
Ratio HDL/LDL & 19 & $0.514 \pm 0.057$ & $0.635 \pm 0.089$ & $0.000^{*}$ \\
\hline
\end{tabular}

Note: *significant when $\mathrm{p}$ value $<0.05$

This activity follows the sequences that have been planned before, the chosen movements are assessed from the upper parts of the body to the lower parts of the body or from head, shoulders, arms, up to the combined movements. The implementation of the main activity moves progressively from single movement on the body up to the simultaneously body movement (Marta, Dinata 2007). Accord to Mann et al (2013) doing the moderate intensity resistance exercise 3 times in a week for 6 weeks can improve the level of HDL-c. The physical activity mechanism that can improve HDL level is Reverse Cholesterol Transport; it is a lipoprotein metabolism process. HDL returns cholesterol from LDL to heart to be resynthesized as bile acids (Murray, 2014). The improvement of HDL level can be mediated by lecithin-cholesterol acyltransferase (LCAT) enzyme. In some experiments, it was reported that there is improvement of LCAT after physical exercise which then can cause many certified cholesterol yang and transported to the main of HDL particle.

This allows HDL to bind the uncertified cholesterol on the surface and cause the improvement on HDL level (Pantouw et al 2014). Lipoprotein lipase helps to move LDL from blood to heart, then it will be changed into bile or secreted thus the LDL level decrease (Haryanto \& Sayogo, 2013). The decrease of LDL cholesterol level is caused by the high content of unsaturated fatty acids (HDL) such as monosaturated fatty acids (oleic acid) and polyunsaturated fatty acids (linoleic acids). HDL can decrease the level of cholesterol by stimulating the change of cholesterol esters to become bile acids and excreted through bile duct. Moreover, it can improve the increase of LDL receptor formation, so the catabolism process of LDL in the blood can be immediately distributed to the tissue. HDL will also decrease the cholesterol level of blood plasma because HDL in the heart is not modified to become LDL and
VLDL, but it tends to undergo an oxidation that produces bile acids.

\section{CONCLUSION}

Fun aerobic gym is one of the efforts to prevent cardiovascular diseases. The intensity of fun aerobic gym is on the moderate level. three treatments in a week for six weeks, this gym can increased the level of HDLc, ratio HDL-c/LDL-c and decreased the level of LDL-c for women suffering from obesity.

\section{REFERENCES}

Dinata M (2007). Langsing dengan Aerobik. Ciputat, Penerbit Cerdas Jaya

Hardani E, Lestariana W (2014). Efek pemberian ekstrak teh hijau (Camellia sinesis (L) O. Kuntze ) var. Assamica terhadap total lemak tubuh dan pro fi 1 lipid wanita dewasa overweight dan obesitas. Jurnal Gizi Klinik Indonesia 10, 209-217

Haryanto A, Sayogo S (2013). Hiperkolesterolemia?: Bagaimana Peran Hesperidin? CDK-200 40, 12-16

Haque ATME, Binti F, Yusoff M, Haidir M, Bin S, Fadhli M, et al (2016). Lipid profile of the coronary heart disease (CHD) patients admitted in a hospital in Malaysia Journal of Applied Pharmaceutical Science 6, 137-142

Kannan U (2014). Effect of Exercise Intensity on Lipid Profile in Sedentary Obese Adults. J Clin Diagn Res 8, 8-11

Kantyka J, Herman D, Roczniok R, Kuba L (2015). Effects of aqua aerobics on body composition, body mass, lipid profile, and blood count in middle-aged sedentary women. Human Movement 16, 9-14 
Kazeminasab F, Sc M, Marandi M, Ph D, Ghaedi K, Ph D (2017). Effects of a 4-week aerobic exercise on lipid profile and expression of LXR a in rat liver. Cell J 19, 45-49

Kelley GA, Kelley KS, Roberts S, Haskell W, Mayer J, Human U (2012). Combined effects of aerobic exercise and diet on lipids and lipoproteins in overweight and obese adults?: A meta-analysis. J Obes 2012

Kelly RB (2010). Diet and exercise in the management of hyperlipidemia. Am Fam Physician 81, 1097-1102

Mann S, Beedie C, Jimenez A (2013). Differential effects of aerobic exercise, resistance training and combined exercise modalities on cholesterol and the lipid profile?: Review, synthesis and recommendations. Sports Med 44, 211-21
Murray RK (2014). Biokimia Harper. 29th Ed. Jakarta, EGC

Pantouw RS, Wongkar D, Ticoalu SHR (2014). Pengaruh Latihan Zumba Terhadap Kadar Kolesterol. Unpublished thesis, 557-561

Rejeki PS, Argarini R, Subadi I (2001). Comparison effect of CV 12 , ST 36 and ST 40 EA on short term energy balance regulation in high fat diet rat. Folia Medica Indonesiana 52, 174-179

Rejeki PS, Wiyasihati SI (2017). Potency of CV12 acupuncture as obesity prevention through mice. Folia Medica Indonesiana 53, 24-28

Sikalak W, Widajanti L, Aruben R (2017). Faktor-faktor yang berhubungan dengan kejadian obesitas pada karyawati perusahaan di bidang telekomunikasi jakarta tahun 2017. No Title 5, 193-201 